\title{
Dispersal Patterns in Costa Rican Mantled Howling Monkeys
}

\author{
Kenneth E. Glander ${ }^{1}$
}

Received February 26, 1991; accepted March 30, 1991

\begin{abstract}
Both male and female juveniles disperse in Costa Rican mantled howling monkeys (Alouatta palliata). $79 \%$ of the males and $96 \%$ of the females leave their natal groups. Males may spend up to 4 years and females up to 1 year as solitaries. Extra-group individuals are faced with only three possibilities, i.e., form a new group by joining another extra-group individual, join an established social group, or remain solitary. Most surviving extra-group individuals join an established social group which contains no kin. Females join with the help of a resident male and once in a group proceed to rise to the alpha position through dyadic interactions. The immigrant female either becomes the alpha female or leaves and tries again in another group. Males challenge the alpha male and either defeat him or remain solitary. Competition with relatives for limited high quality food may be the reason for both sexes leaving their natal groups in howlers. By leaving, the successful immigrants increase their mothers inclusive fitness while suppressing the fitness of nonrelatives instead of remaining natal and competing with relatives for limited food.
\end{abstract}

KEY WORDS: alouatta palliata, migration, competition, bisexual dispersal, cost/benefit, longterm study.

\section{INTRODUCTION}

Dispersal in birds is commonly female-biased (Greenwood and Harvey, 1976; Baker, 1978), while in mammals the dispersing sex is most often male (Lidicker, 1975; Clutton-Brock, 1989). Primates tend to follow

'Department of Biological Anthropology \& Anatomy, Duke University, Wheeler Building, 3705-B Erwin Road, Durham, North Carolina 27705. 
the mammalian pattern in that males are more likely to migrate from the natal group (Pusey and Packer, 1987), but recent studies have documented female-biased dispersal in some New World primates; Alouatta caraya (Rumiz, 1990), Ateles paniscus (Symington, 1990), and Brachyteles arachnoides (Strier, 1990). In fact, Strier (1990), suggests that female-biased dispersal may be the ancestral form of New World primate social organization.

Dispersal of both sexes is common in monogamous primates (Tenaza, 1975; Tilson, 1981) and Callithrichids (Dawson, 1978; Neyman, 1978) but is rare in polygnous primate groups. Bisexual dispersal has been reported for mantled howling monkeys [Alouatta palliata (Glander, 1980; Clarke, 1982)], red howlers [Alouatta seniculus (Crockett and Eisenberg, 1987; Pope, 1989, 1990; Crockett and Pope, 1993)], red colobus [Colobus badius (Struhsaker and Leland, personal communication, cited by Pusey and Packer, 1987)], gorillas [Gorilla gorilla beringei (Watts, 1990)], and hamadryas baboons [Papio hamadryas (Sigg et al., 1982)].

In this paper I present detailed information on the dispersal pattern for Costa Rican mantled howlers (A. palliata). Emigration occurs during the juvenile stage of life, with $79 \%$ of the males and $96 \%$ of the females leaving their natal groups. Both male and female emigrants live as extragroup animals for up to 3 years or more. Extragroup individuals are faced with only three possibilities: to form a new group by joining another extragroup individual, to join an established social group, or to remain solitary. Most surviving extragroup individuals join an established social group which contains no kin. The methods of joining are different for males and females and there are only two possible outcomes for a female; either she becomes the alpha female or she leaves and tries again in another group. Thus, transient dispersal is common for females, while secondary dispersal has been recorded only once in 20 years. No males have been observed to experience either transient or secondary dispersal. This dispersal pattern results in social groups of nonrelated individuals and a prediction that there is low genetic variability in the population.

The conclusion reached in this paper-that mantled howling monkeys have bisexual dispersal-differs from the conclusions of Scott et al. (1978), that this population had male-biased dispersal. The 1978 paper was based on 3 years' of data and only a few documented dispersals.

\section{DEFINITIONS}

In this paper emigration is defined as leaving the natal group. Immigration is defined as joining a nonnatal social group of breeding individuals. Dispersal is defined as movement from the area of birth to the area of 
reproduction. Note that it is possible to emigrate and not disperse by remaining in the natal home range while cutting all former social ties (Moore and $\mathrm{Ali}, 1984)$. Breeding dispersal or secondary dispersal is used to describe individuals which have reproduced in a social unit but then move one or more times between breeding units (Greenwood, 1980). Transient dispersal Itransient immigrants are defined as joining a group and then leaving again within 12 months without reproducing. Extragroup animals are individuals living as solitaries (Moore and Ali, 1984). Natal males and natal females are individuals reproducing in their birth groups (Pusey and Packer, 1987).

\section{SUBJECTS AND METHODS}

For the past 20 years I have been studying marked mantled howling monkeys (Alouatta palliata) at Hacienda La Pacifica in Costa Rica. Quantitative data on emigration, immigration, and dispersal come from my longterm studies at La Pacifica from June 1972 through August 1973 and from July 1989 to February 1991. Qualitative information is taken from my field records collected at La Pacifica during September 1-28, 1970, and then during 2- to 4-week visits I made about every 6 months between 1974 and 1989. Additional data come from a long-term study at La Pacifica (November 1978 through September 1980) by Clarke (1982, 1983, 1990; Clarke and Glander, 1981, 1984).

Since 1972, I have captured 708 howlers at La Pacifica (repeated capture of some animals) for marking and measurement. Capture of the animals was accomplished using the Pneu-Dart system (Glander et al., 1991). Adult females wear unique collars and adult males ankle bands. Ear-tags are used to mark immature animals because collars and ankle bands will not expand as individuals grow. Ear notches are V-shaped pieces of tissue removed from specific locations of the ear. All individuals also have a unique tattoo number on the inside of one thigh. The collars, anklets, and ear-tags permit identification at a distance and the tattoos and ear notches ensure proper identification if all other markings are lost. Individual recognition is $100 \%$ for marked animals. Currently 345 of the estimated 682 howlers on La Pacifica are marked.

\section{Study Site}

Hacienda La Pacifica is a 1980-ha cattle ranch located at the base of the Cordillera de Tiliran, $5 \mathrm{~km}$ northwest of Cañas, Guanacaste, Costa Rica, at latitude $10^{\circ} 28^{\prime} \mathrm{N}$ and longitude $85^{\circ} 07^{\prime} \mathrm{W}$. It is $45 \mathrm{~m}$ above sea level 


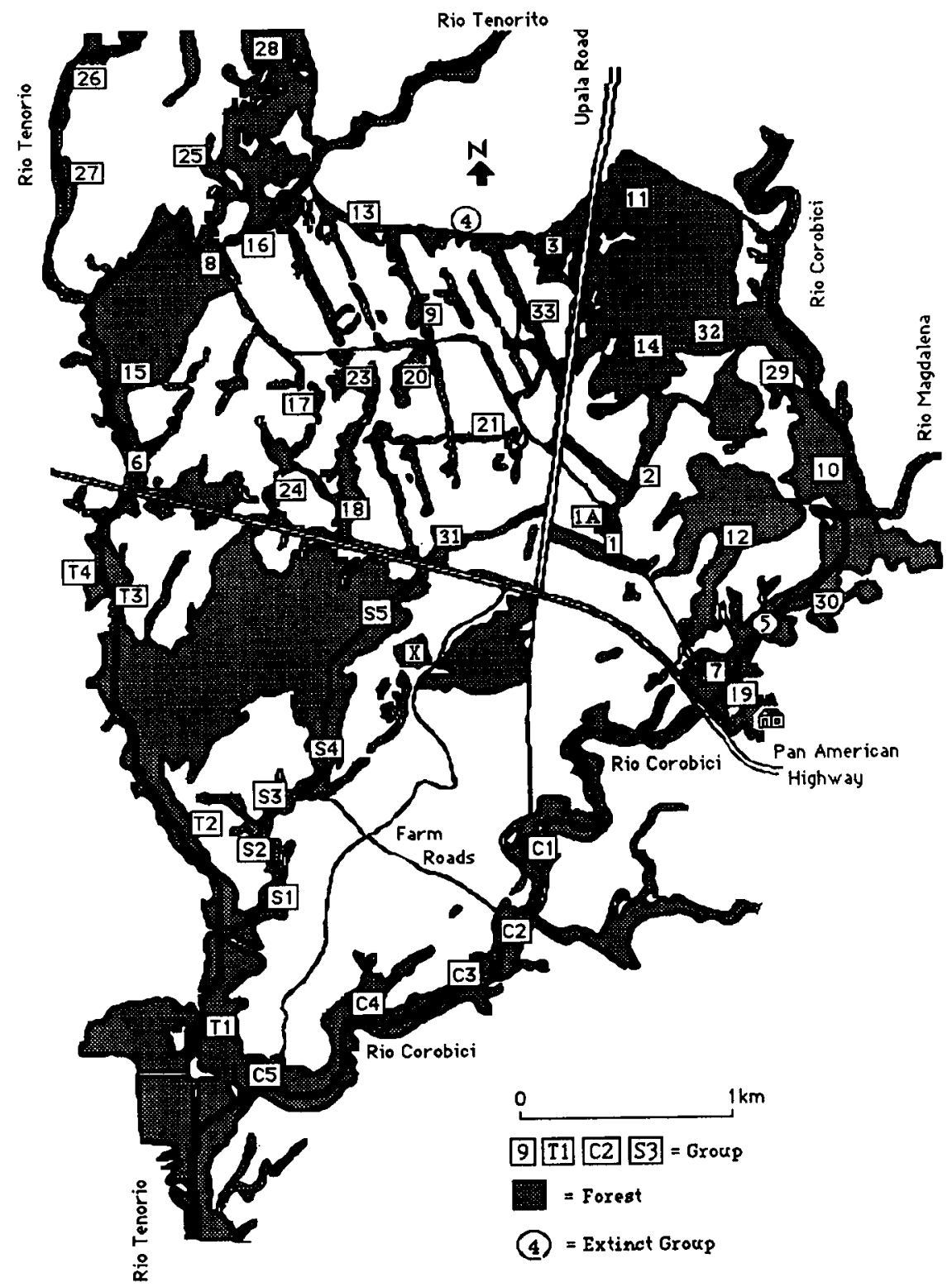

Fig. 1. Map of La Pacifica with location of howler groups. 
and lies within the lowland tropical dry forest life zone (Holdridge, 1967). Although La Pacifica is a working cattle ranch, approximately 600 ha of semideciduous forest remains in several large tracts, as well as windbreak strips and riparian forests (Fig. 1).

Despite (or perhaps because of) the fragmented patches of forest, howlers have been quite successful on La Pacifica. The population density of $74.3 / \mathrm{km}^{2}$ on La Pacifica (Clarke et al., 1986) falls within the population density reported for mantled howlers at other sites: $4.9 / \mathrm{km}^{2}$ at Santa Rosa National Park, Costa Rica (Fedigan et al., 1985); $23 / \mathrm{km}^{2}$ at Los Tuxtlas in Mexico (Estrada, 1982); and $91.7 / \mathrm{km}^{2}$ on Barro Colorado Island, Panama (Milton, 1982). Several groups of Cebus capucinus live in the forest south of the Pan American Highway (Fig. 1).

\section{Study Population}

There are currently 44 social groups of howlers on La Pacifica (Fig. 1). In a partial census done in 1984, Clarke et al. (1986) found the average group size for 16 groups to be 15.5 . The average group size of my primary study group (Group 7) has averaged 15.6 for the past 20 years (Glander unpub.). Using the lower of these two averages, the current La Pacifica howler population is estimated to be 682 .

\section{Study Groups}

Group 7 (Fig. 1) has been my primary study group since 1970. Group 19 came into existence in 1980 and has been studied since then. Daily observations of Groups 1 and 33 were begun in September 1989 and continue. Other groups are censused once a year. Groups 1 and 33 are dry forest groups, while Groups 7 and 19 live in a riparian habitat (Fig. 1).

\section{RESULTS}

\section{Emigration and Dispersal}

A total of 81 births (40 males, 32 females, 4 unknown) have been recorded in Groups 7 and 19 since 1972. Of these 81 births, 32 infants died before they were 12 months old and 8 individuals $(5$ males and 3 females) are still in the group as infants or early juveniles. Thus, the pool of potential emigrants from these groups was 41 individuals (14 males and 27 females) (Table I). Only 4 of the 41 remained natal ( 3 males and 1 
Table I. Emigration and Natal Individuals in Groups (Gp) 7 and 19

\begin{tabular}{|c|c|c|c|c|c|}
\hline Infant & Sex & Born & Date left ${ }^{a}$ & $\begin{array}{l}\text { Emigration } \\
\text { age } \\
\text { (months) }\end{array}$ & Fate \\
\hline Bonnie & f & Jul-71 & Natal & & Died 8/81 \\
\hline Orange & f & Apr-73 & Aug-76 & 40 & $?$ \\
\hline Yatzie & f & May-73 & Jan-77 & 44 & $?$ \\
\hline un-named & f & Jan-75 & Jun-78 & 41 & $?$ \\
\hline un-named & f & Feb-75 & Apr-78 & 38 & $?$ \\
\hline un-named & f & Feb-77 & Oct-78 & 20 & $?$ \\
\hline Homely & f & Feb-77 & Nov-78 & 22 & $?$ \\
\hline Tala & f & Feb-77 & Dec-79 & 34 & Member Gp 5 \\
\hline Yolo & f & Oct-78 & Jul-80 & 21 & $?$ \\
\hline Bell & f & Oct-78 & Oct-81 & 36 & $?$ \\
\hline Gremlin & f & Feb-79 & Jun-82 & 40 & $?$ \\
\hline Skipper & f & Jun-80 & Jul-83 & 37 & $?$ \\
\hline Bean & f & Aug-80 & Feb-83 & 30 & $?$ \\
\hline Gollum & f & Sep-80 & Jun-83 & 33 & Member Gp 12 \\
\hline Chipper & f & Nov-81 & May-84 & 30 & $?$ \\
\hline Poppy & f & Aug-82 & Feb-84 & 18 & $?$ \\
\hline Jasmine & f & Nov-82 & May-84 & 18 & $?$ \\
\hline Greta & $\mathrm{I}$ & Feb-83 & Jun-86 & 40 & $?$ \\
\hline Robin & i & May-83 & May-86 & 36 & $?$ \\
\hline Lily & f & Sep- 83 & Jun-86 & 33 & $?$ \\
\hline Moxie & f & Jan-84 & Jul-86 & 30 & $?$ \\
\hline Patch & f & Jun- 84 & Aug-86 & 26 & $?$ \\
\hline Micki & f & Jun-85 & May-89 & 47 & $?$ \\
\hline Jessic & f & Jun-85 & Dec-88 & 42 & Solitary \\
\hline Maria & f & Nov-87 & Aug-90 & 33 & $?$ \\
\hline Christy & $\mathrm{f}$ & Jan-88 & Aug-90 & 31 & $?$ \\
\hline Charlie & $\mathrm{m}$ & Jun-71 & Apr-75 & 46 & $?$ \\
\hline Able & $\mathrm{m}$ & Jun-71 & Natal & & Died $5 / 77$ \\
\hline Shadow & m & May-72 & Feb-74 & 21 & $?$ \\
\hline un-named & $\mathrm{m}$ & Jan-75 & Oct-76 & 21 & $?$ \\
\hline un-named & $\mathrm{m}$ & Feb-77 & Oct-78 & 20 & $?$ \\
\hline Yogi & $\mathbf{m}$ & Feb-77 & Apr-79 & 26 & $?$ \\
\hline Bandit & $\mathrm{m}$ & Sep-77 & Dec- 78 & 15 & Member Gp 19 \\
\hline Roddy & $\mathrm{m}$ & Feb-82 & Natal & & Died $3 / 86$ \\
\hline Ripple & $\mathrm{m}$ & Jan-84 & Aug-85 & 19 & Died $8 / 85$ \\
\hline Roo & $\mathrm{m}$ & Aug-84 & Natal & & Member Gp 19 \\
\hline Alvin & $\mathrm{m}$ & Feb-86 & Apr-88 & 26 & $?$ \\
\hline Leo & $\mathrm{m}$ & Aug-86 & Nov-87 & 15 & $?$ \\
\hline Jet & $\mathrm{m}$ & Sep-86 & Aug-89 & 35 & Solitary \\
\hline Marcus & $\mathbf{m}$ & May-89 & Sep-90 & 16 & $?$ \\
\hline
\end{tabular}

${ }^{a}$ Estimated date of leaving is halfway between the last time the individual was seen in the group and the first time it was not seen in the group.

female). The age at emigration of juvenile males (21.9 months; $N=11$ ) is significantly younger than that for emigrating females (32.8 months; $N$ 
$=26, F=12.53, P=0.001$ ). One emigrating Group 7 male (Bandit) established himself in a part of the home range no longer used by Group 7

Table II. Immigration, Transient Dispersal, and Secondary Dispersal for 1970-1990

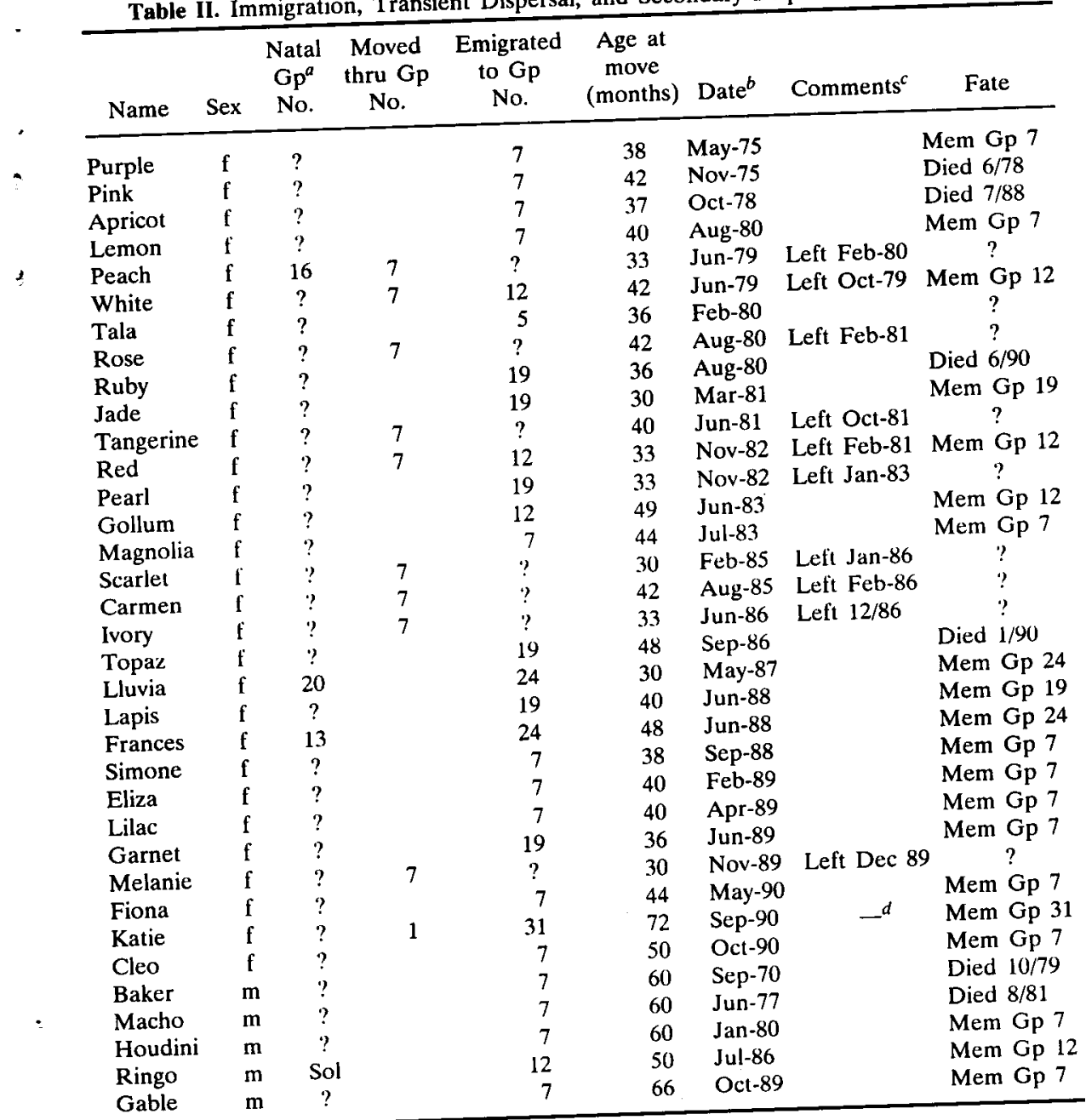

${ }^{a}$ Group.

${ }^{b}$ Estimated date of appearance is haltway between the last tir

the immigrant and the first time it was seen in the group. Estimated date of leaving is halfway between the last

- group and the first time it was not seen in the group. paper. Spent more than 3 years in Group 1. 
and formed a new group in 1980 (designated Group 19). Two of the recent Group 19 emigrants are currently extragroup animals in the home range of Group 19 and 2 females from Group 7 successfully joined nearby groups, but the fate of the other 33 emigrating individuals is unknown.

The movement of an additional 35 individuals ( 5 males and $30 \mathrm{fe}-$ males) has been documented (Table II). Fourteen ( 4 males and 10 females) of these were immigrants to Group 7. An additional nine females were transient immigrants to Group 7. Two of these transient immigrants (Red and White) were later found as full-fledged members of Group 12, an adjacent group (Fig. 1). The fate of the other seven transients is unknown.

The average age of transient immigrants to Group 7 was significantly less than that of the successful immigrating females (Transients-36.1 months, $N=9$; successful: -41.3 month; $N=10 ; F=6.04, \mathrm{P}=0.025)$. The average age of immigrating males to Group 7 was 61.5 months (Table II).

\section{Natal Individuals}

In the 20 years of this study, two males (Able and Roddy) and one female (Bonnie) remained natal in Group 7 and one male (Roo) remained natal in Group 19. Group 7 contained two adult males during the time Able was maturing, and the group size was 18 with 7 sexually adult females, when he assumed the alpha position. There was only one adult male at the time Roddy was maturing and the group size was 15,8 sexually adult females, when he became the alpha male. Able was 45 months old and Roddy was 42 months old when they became the alpha males. Able's mother was the second-ranking female at the time he assumed the alpha male role. Roddy's mother was the lowest-ranking female at the time he became the alpha male. Bonnie matured and assumed the alpha female position during the time when Able became the alpha male. Bonnie was 38 months old when she became alpha and her mother was the second lowest-ranking female.

The Group 19 natal male (Roo) is currently the alpha male. Roo was the first male born in Group 19. The only adult male in the group at the time he was maturing and assumed the alpha position was his father, Bandit. Roo was 41 months old, and his mother was the second ranked of two females when he assumed the alpha position.

In all three cases the natal males did not have to fight for the alpha position; their fathers accepted them as alpha. The fathers remained in the group but did not compete with their sons for access to estrous females or food. Bandit was 11 years old when his son (Roo) took over the alpha position in Group 19, Baker was 12 years old when his son (Able) became 
the alpha male in Group 7, and Houdini was 11 years old when his son (Roddy) assumed the alpha position in Group 7.

\section{Dispersal Distance}

The average distance for dispersing females was $1300 \mathrm{~m}(N=5)$, but the actual distance traveled is likely to be greater since some females are transients. For example, Table II shows that a female (Lluvia), born in Group 20, joined Group 24, which was not the nearest group to her natal group (Fig. 1). To reach Group 24 she had to cross open ground. A female (Frances), born in Group 13, also joined Group 24. She also had to cross open ground to reach Group 24 (Fig. 1). The straight-line distance in these two transfers is about 800 and $1500 \mathrm{~m}$, respectively. The longest documented dispersal distance for the study population is a female's (Peach) move from her natal Group 16 to Group 7, a distance of about $3000 \mathrm{~m}$ (Fig. 1). To reach Group 7, she had to cross a highway (Upala Road) and probably come to the ground several times. She was one of the transients in Group 7 and her ultimate fate is unknown.

\section{Cause of Emigration}

Emigration by juveniles is not voluntary but is forced by resident adult males and females. Clarke (1982) noted that adult aggression toward juveniles was always directed toward a nonrelative. She observed resident adult males harming natal female juveniles and reported that two female juveniles in Group 7 (Yolo and Bell) sustained severe tail wounds from a resident male (Macho). Macho was not their father (Clarke 1982). The damage involved multiple lacerations and broken tails. Clarke (1982) noted that Yolo emigrated soon after the attack. In addition, Clarke (1982) reported that five of eight juveniles emigrated from Group 7 during her 2 year study.

A juvenile male (Bandit) sustained a severely lacerated tail on May 18,1978 , during a takeover of Group 7 (personal observation). Capture on November 17, 1978, verified that his tail had been broken and that he was missing the distal two phalanges of left toes III and IV. Bandit was continuously harassed by the new male and finally left his natal group in December 1978. He eventually formed a new group (Group 19).

Roo (Bandit's first son) forced his brother Jet (Bandit's second son) to leave Group 19 in August 1989, just before Jet was 3 years old. Jet has remained solitary in the home range of Group 19. Roo has been observed to chase Jet whenever Jet approaches the group. These chases often last for several hours. 


\section{Length of Extra-Group Existence}

The amount of time spent solitary differs for the sexes and may be influenced by the age at emigration since both males and females have to fight their way into a group and relative body size contributes to likely success in aggressive interactions. The average body weight of transient immigrants (3935 $\mathrm{g} ; N=9$ ) was less than the average body weight of successful immigrants (4369 $\mathrm{g} ; N=13$ ) (Glander, unpublished). Although this difference is not statistically significant $(F=2.67, P=0.12)$, body weight affects the likely success or failure of an immigrating female in her contest with group females as she attempts to rise above them in the dominance hierarchy.

Females tend to spend from 6 to 12 months solitary, while males may spend more than 36 months alone. For example, the average age of emigrating males from Group 7 (Table I) was 21.9 months $(N=11)$, while the average age of immigrating males to Group 7 (Table II) was 61.5 months $(N=4)$. Obviously these are not the same males, but if these numbers are used as the general pattern for dispersing males on La Pacifica, then males spend about $\mathbf{4 0}$ months as extragroup animals. A similar pattern exists for females. The average age for emigrating females from Group 7 (Table I) was 32.6 months $(N=26)$, while the average age for successful immigrating females (Table II) was 41.3 months $(N=9)$, a difference of 8.7 months spent as solitaries.

\section{Coping with Extragroup Existence}

Upon leaving their natal groups both male and female juveniles operate as extragroup individuals. They frequently stay in the home range of their natal group for a period of time and then gradually begin to increase the distance they travel by visiting the home ranges of other groups. As solitaries they are secretive and do nothing to attract attention. Occasionally extragroup individuals will associate briefly with other solitaries of either sex. There are only three choices for extragroup individuals; (1) to join another solitary individual and begin a new group, (2) to join an established group, or (3) to remain solitary.

\section{Female Method of Joining an Established Group}

The following descriptions are distilled from 31 immigrant events which occurred in Groups 7 and 19. The overall pattern was the same, but the timing varied and the method of joining an established group was different for males and females. Females begin the process by following or 
shadowing an established group. The response of resident females is to give a high-pitched call upon first sighting the extragroup female and then to chase her if she approaches the group. The chases are carried out by two to five females and often cover several hundred meters. If caught, the group females mob the solitary and pull her hair or bite her. Occasionally the solitary female is trapped and forced to escape on the ground. The solitary female continues to shadow the group, often moving just close enough to make her presence known but not close enough to trigger a chase by the resident females. After several months of this testing (a solitary female may test more than one group), the extragroup female decreases the distance between herself and her chosen group. One or more of the resident males now play a role. The males (as individuals) approach the extragroup female (thus preventing the resident females from chasing her), sniff her vulva, and either copulate with her, if she is in estrus, or move back to the group, if she is not. In fact, the decreased distance from the group by the extragroup female may coincide with her being sexually receptive. If copulation occurs, the male usually spends a few hours with the female in consort, which brings her into the group because the resident females cannot chase her during this time. Once she achieves this entry into the group with the male's help, she no longer is chased by the resident females and is a group member.

Almost immediately after becoming a group member, the former extragroup female begins actively to fight her way up the female dominance hierachy. She begins by easily supplanting the juveniles of both sexes. This is followed by her attacking the lowest-ranking female and gradually working her way up through the female hierarachy (in order from lowest to highest rank) by attacking the next higher-ranking female as she is successful in supplanting each lower-ranking female. Rank is determined from dyadic interactions ordered in a matrix. The winner is able to supplant the loser from feeding, resting, sleeping, and drinking sites (Glander, 1980). An individual is dropped in rank whenever the formerly higher-rank individual is supplanted by an animal formerly ranked lower. The attacks range from low-level harassment to hair-pulling and biting. These attacks can be costly; Eliza lost an eye while she was moving up through the female hierarchy in Group 7. And six of the nine females, which have been successful immigrants to Group 7, have lost their first infants while they were achieving the alpha position. I saw the infant of a rising female drown in the river because it was pulled off its mother during one of her fights. Three infants of newly alpha females were killed by invading males (Clarke, 1983). Two of the nine (Fiona and Cleo) have not had their first infants. Only 1 of the 10 successful immigrants (Simone) did not lose her first infant as 
Table IIl. Length of Tenure for Alpha Males and Females in Group 7

\begin{tabular}{lcccc}
\hline \multicolumn{1}{c}{ Name } & Tenure & $\begin{array}{c}\text { Actual } \\
\text { months }\end{array}$ & Predicted $^{a}$ & \\
Males & & & & \\
Baker & $9 / 70-11 / 75$ & 63 & 35 & Shot by tourist \\
Able & $12 / 76-4 / 77$ & 16 & & \\
Baker & $4 / 77-10 / 78$ & 19 & & \\
Macho & $11 / 78-7 / 80$ & 21 & & \\
Houdini & $8 / 80-8 / 85$ & 61 & & \\
Roddy & $9 / 85-7 / 87$ & 23 & & \\
Houdini & $7 / 87-9 / 89$ & 27 & & \\
$\quad$ Average & & & & \\
Females & & & & \\
Green & $8 / 72-8 / 74$ & 24 & & \\
Bonnie & $8 / 74-1 / 76$ & 17 & & \\
Purple & $1 / 76-1 / 78$ & 24 & & \\
Pink & $1 / 78-4 / 79$ & 15 & & \\
Apricot & $4 / 79-3 / 81$ & 23 & & \\
Lemon & $3 / 81-11 / 84$ & 44 & & \\
Magnolia & $11 / 84-3 / 88$ & 52 & & \\
Simone & $3 / 88-3 / 89$ & 12 & \\
Eliza & $3 / 89-12 / 89$ & 8 & \\
Lilac & $12 / 89-5 / 90$ & 4 & \\
Fiona & $5 / 90-1 / 91$ & 8 & & \\
Average & & 21 & & \\
\hline
\end{tabular}

${ }^{a}$ Tenure for Able and Roddy estimated by adding length of time to takeover by Macho and Gable.

she became the alpha female. The average length of time Group 7 females spent as alpha was 21 months (Table III).

There are only two possible results for an extragroup female attempting to join an established group. If she is successful in supplanting every resident female, she becomes the alpha female and every other female drops one rank. If she is not successful in becoming alpha, she does not stop in the middle ranks but leaves and tries another group. Nine of the females which attempted to join Group 7 and one female immigrant to Group 19 were unsuccessful in becoming alpha and left (transients in Table II). It is possible that transient females are pregnant when they leave since their stay may be as long as 12 months.

\section{Male Method of Joining an Established Group}

Two different types of male takeovers have been observed, i.e., with and without a fight. Both types begin with the males spending time as a solitary animal (during which time they increase in body size) before they 
target a specific group. The extragroup male begins by shadowing his target group and then gradually reduces his distance in following the group. He is chased away by one or more of the resident males (just as the extragroup females, the extragroup males may test more than one group).

Ultimately, in the takeovers with a fight, the extragroup male attacks the alpha male and either defeats the alpha male or loses the fight and remains solitary (Glander, 1980; Clarke, 1982, 1983; Clarke and Glander, 1984). Unlike the females, males attack the highest-ranked male rather than going up step by step. I have witnessed three of these attacks. In each case the fight was silent, violent and short (about $90 \mathrm{sec}$ ). The losing male was severely wounded and chased from the group by the victor. Wounds consisted of deep lacerations on the face, arms, hands and shoulders. If the invading male is successful in defeating the resident alpha male, he proceeds to kill infants (Clarke, 1983; Clarke and Glander, 1984). After a period of several days or weeks of being chased out of the group each time he approaches, the defeated former alpha male is allowed to rejoin his group, but he is now subordinate to the successful invading male.

Takeovers without a fight include cases where a natal male attained the alpha position. Herein the alpha male prevents his son or the invading male from copulating with estrous females at first, but eventually the son or the invading male asserts himself without a fight and, from that time, regularly prevents the former alpha male from copulating with estrous females (Clarke, personal communication).

If more than one male is present in a group, a linear dominance hierarchy is established. Just as in females, rank for males is determined from dyadic interactions ordered in a matrix. The winner is able to supplant the loser from estrous females, as well as from feeding, resting, sleeping, and drinking sites (Glander, 1980). The hierarchy is inversely linked to age (Glander, 1980; Jones, 1980a) - the youngest adult male is alpha and the second-ranked male is younger than the third ranked male, etc. These subalpha males often leave their groups for 1 to 2 weeks, during which time they visit nearby groups, but they always come back to their groups. There have been no instances of these older males experiencing secondary dispersal.

\section{Secondary Dispersal}

Secondary dispersal has never been observed for males. The only documented cases of secondary dispersal for females occurred after the following events. In September 1989, Group 1 contained nine animals (one adult male, seven adult females, one juvenile). The adult male (Peanuts), one adult female, and a juvenile from Group 1 were found dead on January 
12,1990 . On January 20,1990 , another female was found dead. This left the five remaining females of Group 1 without a male. One of the females disappeared in late January 1990. The other four remained alone in their home range during the next 4 months. During this time several of the Group 1 females crossed the open area between the home ranges of Group 1 and Group 1A (Fig. 1) to join Group 1A temporarily. Group 1A consisted of one adult male (Jasper), one adult female, and one juvenile. Each time, only one female would cross, spend a few days with Group 1A, during which she copulated with Jasper, and then return to the Group 1 home range. In April 1990 all four females crossed to the home range of Group 1A. Group 1A (with the former Group 1 females) then began to use the home range of Group 1 in addition to the Group 1A home range. To do this required crossing open ground between the two areas.

Occasionally, one or more of the former Group 1 females would separate from Group 1A and spend time solitary in a different part of the range. Also, in May 1990 and during subsequent months, two solitary females and two solitary males were found in what had been Group 1's home range, but never in association with any of the former group 1 females, which were now part of Group 1A.

In september 1990, a male (Ghengis) from the home range of Group 21 (Fig. 1) took over Group 1A. Jasper was severely wounded and his body was found 2 weeks after the takeover. He was approximately 18 years old when he died. Shortly after the takeover one of the adult females (Katie) left the area and in October was found to be a member of Group 31. She was 7 years old at the time of her secondary dispersal. Katie's transfer and the three Group 1 females joining Group 1A are the only documented cases of secondary dispersal among the La Pacifica population but should be considered a special case because of the death of the adult male in their original group.

\section{DISCUSSION}

Among polygynous primates, habitual dispersal of both sexes occurs in gorillas (Watts, 1990), hamadryas baboons (Sigg et al., 1982), red colobus (Struhsaker and Leland, personal communication, cited by Pusey and Packer, 1987), red howling monkeys (Crockett and Pope, 1993), and mantled howlers. Taxonomically these species represent similarity (two howler species) and diversity (two New world monkeys, two Old World monkeys, and one great ape). A highly unusual aspect of the bisexual dispersal systems found in these five primate species is the fact that they appear to be different from each other. 
The differences are in terms of (1) whether or not the dispersing individual spends time as a solitary or immediately transfers to an established group, (2) whether reproduction is achieved by joining an established group or by forming a new group, (3) whether secondary dispersal occurs, and (4) the distance traveled by dispersing individuals. For example, female gorillas move directly from one social group to another and do not spend time as extragroup animals (Harcourt et al., 1976). Occasionally female gorillas leave a social group to join a solitary male and it is not uncommon for female gorillas to move between groups more than once (Harcourt et al., 1976). Some male gorillas take over their natal groups when their fathers die, but most leave to become solitary and eventually form new groups as emigrating females join them (Steward and Harcourt, 1987). Both male and female hamadryas baboons leave their natal groups, but only females transfer between groups (Sigg et al., 1982). Male hamadryas baboons leave their natal group but remain in their natal clans, where they help to prevent nonclan males from stealing clan females (Sigg et al., 1982). Some red colobus males emigrate and become solitary, but male transfer is uncommon, while all females transfer as juveniles (Struhsaker and Leland, personal communication, cited by Pusey and Packer, 1987).

In red howlers, $98 \%$ of the males and $79 \%$ of the females emigrate, but none of the emigrating females join established groups, while about $50 \%$ of the emigrating males successfully join nearby groups (Crockett and Eisenberg, 1987; Pope, 1989; Crockett and Pope, 1993). Red howler males have secondary dispersal, while red howler females do not (Crockett and Pope, 1993). Secondary dispersal in mantled howlers is extremely rare. Although Jones (1980b) reported several cases of secondary dispersal for mantled howlers at La Pacifica in a study that covered 7 months, no secondary dispersal for adult male mantled howlers have been observed in my 20-year study, and the only secondary dispersal for adult females during the same 20 years occurred after an established group lost its only adult male.

Unlike the females of the other three species, female red and mantled howler females spend time as extragroup individuals. Female mantled howlers leave their natal group as juveniles and spend up to 1 year as solitaries before joining an established social unit. Females of the closely related red howler emigrate from their natal group but are not able to join established social units; instead, the only way that they can reproduce is to join a solitary male to form a new group in available habitat (Crockett and Pope, 1993). Population expansion may be forcing the red howlers into marginal habitats (Rudran, 1979; Crockett, 1984) or it is possible that these excess females are taking advantage of regenerating forests which gradually become capable of sustaining red howler groups. 
There is evidence from La Pacifica to support this idea of regenerating forests becoming habitable. Most forest on La Pacifica appear to be at or near their carrying capacities, and opportunities for female mantled howlers to join a solitary male and form a new social group are rare and probably limited. In 20 years there have been only two documented cases of new groups forming. But an area to the south of the Pan American Highway currently contains regenerating forests with a low howler population density (Fig. 1). Surveys of this area since 1988 indicate that it is reaching the level of habitability for howlers. In fact, a new social group was established in this area in June 1990. I expect more new groups to establish themselves as these forests continue to regrow.

Juvenile male mantled howlers leave their natal groups and may spend more than 3 years as extragroup animals. About $50 \%$ of natal red howler males emigrate and join an adjacent established group or form a new group near their natal groups (Crockett and Pope, 1993). Adult male red howlers experience breeding dispersal (Crockett and Pope, 1993), while breeding dispersal does not occur in male mantled howlers. Since red howler males are older at the time of emigration [average leaving age of 60 months (Crockett and Pope, 1993)] than mantled howler males (average leaving age of 22.5 months), red howler males require less time as extragroup animals in order to obtain their adult size. Juvenile males of either species probably have little chance to win in competition with adult males until they attain their full body sizes. The average body weight for successful invading males was $5545 \mathrm{~g}(N=3)$; the average weight for 10 resident males was $5795 \mathrm{~g}$ (Glander, unpublished.)

Presumably the differences among gorillas, hamadryas baboons, and red colobus, as well as the differences between red and mantled howlers, are brought about by one or more of the following most cited reasons for dispersing: (1) avoidance of inbreeding (Darling, 1937; Itani, 1972; Wilson, 1975; Packer, 1979; Melnick and Pearl, 1987), (2) competition for mates (Waser and Jones, 1983; Moore and Ali, 1984), and (3) competition for environmental resources (Howard, 1960; Lidicker, 1962).

Pusey and Packer (1987) suggest that inbreeding avoidance is the best explanation for natal transfer in gorillas and that competition for mates is a major force in hamadryas dispersal patterns. More information is required in order to explain dispersal in red colobus.

The competition for mates hypothesis predicts that males instead of females should be in competition for mates and the most likely sex to disperse (Dobson, 1982). If we accept competition for mates as the reason for the dispersal of male red and mantled howling monkeys, why do female red and mantled howlers also disperse? A comparison of the costs and benefits experienced by dispersing females may provide some answers. 
The costs to an emigrating red howler female include a higher rate of injury (Crockett and Pope, 1988; Sekulic, 1982), harassment by resident animals, foraging in an unknown habitat, and delayed age at first breeding (Crockett and Pope, 1993). The costs to dispersing mantled howler females include exposure to predation, harassment from resident individuals, injury, loss of her first infant, and foraging for food in an unknown habitat. Delayed breeding could be a factor for mantled howlers if there is a delay in finding and entering an established group or a delay in pairing with a solitary male to form a new group (rare occurrence for mantled howlers but common in red howlers). The average age of successful immigrating mantled howler females was 41.3 months, which is near the age (43 months) at which first birth occurs (Glander, 1980). Even if a female mantled howler is a transient immigrant, she does not experience delayed reproduction as a result of transience because she is pregnant when she leaves and her first infant is born in the group where she is a successful immigrant. She may lose this first infant during her fights to gain the alpha position. Extragroup females are commonly found, but no solitary female has ever been found with an infant.

Finding food in a strange habitat is certainly a significant cost for extragroup mantled howler females just as it is for solitary red howler females. Pope (1989) found that the diet of extragroup red howler females was significantly lower in crude protein and significantly higher in fiber than the diet of group females. Solitary mantled howlers face a similar situation. The trees in the Costa Rican mantled howlers' home ranges are known to vary in the nature of the nutrients and chemical protection present in their leaves (Glander, 1979, 1981). Being unfamiliar with the habitat means that the solitary females are not aware of the location of high quality food, i.e., food that is high in nutrients and low in secondary compounds. Food quality also affects body condition since the harassment and chasing by resident individuals increase the extragroup animal's energy expenditure. The resident individuals prevent the solitaries from replacing the lost energy because of the chases or because the residents harvest the high-quality food and leave only low-quality items for the solitary animal.

Thus, there are significant costs to dispersing for females, but the cost of remaining natal and competing with relatives for limited food may be even more damaging. There is a linear dominance hierarchy among mantled howlers that is inversely linked to age (Glander, 1980; Jones, 1980a). And rank is important because high rank ensures access to limited resources. Chemical analysis indicates that the food of these folivores is limited in both quantity and quality by the presence of plant secondary compounds (Glander, 1979, 1981, 1982). The dominance hierarchy is most evident during feeding, suggesting that there is competition for food. In fact, mothers regularly supplant their offspring in feeding situations 
(Clarke, 1982). Competition for limited food dictates that the competitively subordinate age and sex groups be the dispersers (Dobson, 1982). For mantled howlers those are the juveniles of both sexes. Cooperation with kin to defend food resources (Wrangham, 1980) can benefit individuals only if there is sufficient high-quality food available. By joining other groups, the dispersing individuals compete with nonrelatives instead of staying in their natal group and competing with kin for the limited food.

The high infant mortality of low-ranking female mantled howlers-60\%, compared to $28 \%$ for high-ranked females (Glander, 1980)-indicates that low-ranking individuals are at a productive disadvantage. These data, plus the fact that mothers compete directly with their offspring for food (Clarke, 1982), suggest that the costs of remaining natal may outweigh the heavy costs of dispersing.

Following Wrangham's (1980) model, these mantled howlers must be classified as nonfemale bonded (females do not breed natally). Unlike his female-bonded groups, where related females cooperate against females in other groups, mantled howler females are unrelated and cooperate against other groups in defense of high-quality food patches (individual food trees with fruits and new leaves). In fact, the intragroup competition and female dispersion seen in my study groups fit the inclusive fitness theory which suggests that relatives should disperse in order to avoid imposing costs on their kin (Hamilton, 1964). In this model, successful immigrants increase their mother's inclusive fitness while suppressing the fitness of nonrelatives instead of remaining natal and competing with relatives for limited highquality food. According to Hamilton's theory, dispersal should not be to adjacent groups where intergroup competition would affect kin. Successful dispersing individuals on La Pacifica have joined nearby groups, but none joined a group whose home range overlapped with the home range of the dispersing animal's natal group. An attempt to join an adjacent group which shares home ranges may be one reason for lack of success (transient immigrants).

The discussion up to this point has been about competition for mates and competition for limited resources. What role does inbreeding avoidance play in both red and mantled howler social organization? On initial analysis, inbreeding avoidance does not appear to play any role since the males of both red and mantled howlers leave their natal groups. If one sex leaves, the other should be able to remain natal without the population experiencing inbreeding depression (Dobson, 1982).

The possibility of inbreeding depression would exist if females remained natal and dispersing males occupied the breeding male role longer than it took for their daughters to mature. This is exactly what happens in red howlers. The length of tenure for male red howlers is 8.2 years (if 
there is a coalition of relatives) and the age at first birth for a female red howler is 5.1 years (Crockett and Pope, 1993). Only one adult male sires offspring in red howlers even if there are two adult males in a group (Pope, 1989 , 1993). Thus, there is a high probability that a natal female would breed with her father with the potential for inbreeding depression.

For mantled howlers, the average tenure for alpha males is 46 months (Table III) and the age at first birth for females is 43 months (Glander, 1980). Thus, a natal female mantled howler is less likely to mate with her father.

Both red howling monkeys and mantled howling monkeys have bisexual dispersal, but there are differences in the dispersal characteristics, despite the fact that these two species are closely related. It is unlikely that a single hypothesis can explain the dispersal patterns found in red and mantled howling monkeys, but in mantled howling monkeys, competition for limited food might have a greater impact than competitions for mates or inbreeding avoidance.

\section{ACKNOWLEDGMENTS}

I thank E. O. Smith and D. S. Sprague for the invitation to participate in this symposium. Special thanks go to Stephan Schmidheiny and the Board of Directors of Hacienda La Pacifica for their permission to work on La Pacifica and for their continued support and help. Thanks are due to Margaret Clarke and Evan Zucker for their many contributions to the long-term success of this project and for their friendship. Thanks go to Luisa Moreno, Isabel Sales, Andrew and Karen Rendall, Laura Robinson, Patty Henry, Andrew and Beatrice de Vries, Holly Ferrette, Karen Richardson, and Beatrice Blanchard for their help in collecting behavioral and ecological data during the 1989-1991 phase of the project. I am grateful to the many Earthwatch volunteers who have helped with the marking and measuring efforts on La Pacifica. This research has been supported by NSF Grant BNS 8819733, Duke University Research Council grants, Duke University Biomedical Research Support grants, a COSHEN-Pew grant, and grants from The Center for Field Research.

\section{REFERENCES}

Baker, R. R. (1978). The Evolutionary Ecology of Animal Migration, Hodder \& Stoughton, London.

Clarke, M. R. (1982). Socialization, Infant Mortality and Infant-Nonmother Interactions in Howling Monkeys (Alouatta palliata in Costa Rica. Dissertation, University of California, Davis. 
Clarke, M. R. (1983). Infant-killing and infant disappearance following male takeovers in a group of free-ranging howling monkeys (Alouatta palliata) in Costa Rica. Am. J. Primatol. 5: 241-247.

Clarke, M. R. (1990). Behavioral development and socialization of infants in a free-ranging group of howling monkeys (Alouatta palliata). Folia Primatol. 54: 1-15.

Clarke, M. R., and Glander, K. E. (1981). Adoption of infant howling monkeys (Alouatta palliata). Am. J. Primatol. 1: 469-472.

Clarke, M. R., and Glander, K. E. (1984). Female reproductive success in a group of freeranging howling monkeys (Alouatta palliata) in Costa Rica. In Small, M. (ed.), Female Primate: Studies by Women Primatologists, Alan R. Liss, New york, pp. 111-126.

Clarke, M. R., Zucker, E. L., and Scott, N. J., Jr. (1986). Population trends of the mantled howler groups of La Pacifica, Guanacaste, Costa Rica. Am. J. Primatol. 11: 79-88.

Clutton-Brock, T. H. (1989). Female transfer and inbreeding avoidance in social mammals. Nature 337: 70-71.

Crockett, C. M. (1984). Emigration by female red howler monkeys and the case for female competition. In Small, M. F. (ed.), Female Primates: Studies by Women Primatologists, Alan R. Liss, New York, pp. 159-173.

Crockett, C. M., and Eisenberg, J. F. (1987). Howlers: Variations in group size and demography. In Smuts, B. B., Cheney, D. L., Seyfarth, R. M., Wrangham, R. W., and Struhsaker, T. T. (eds.), Primate Societies, University of Chicago Press, Chicago, pp. 54-68.

Crockett, C. M. and Pope, T. R. (1988). Inferring Patterns of aggression from red howler monkey injuries. Am. J. Primatol. 14: 1-21.

Crockett, C. M. and Pope, T. R. (1993). The consequences of sex differences in dispersal for survival and behavior of juvenile red howler monkeys. In Pereira, M. E., and Fairbanks, L. (eds.), Juvenile Primate: Tactics of Social Behvior, Oxford University Press, New York (in press).

Darling, F. F. (1937). A Herd of Red Deer, Oxford University Press, Oxford.

Dawson, G. a. (1978). Composition and stability of social groups of the tamarin, Saguinus oedipus geoffroyi, in Panama: Ecological and behavioral implications In Klieiman, D. G. (ed.), The Biology and Conservation of the Callitrichidae, Smithsonian Institution Press, Washington, D.C. pp. 23-37.

Dobson, F. S. (1982). Competition for mates and predominant juvenile male dispersal in mammals. Anim. Behav. 30: 1183-1192.

Estrada, A. (1982). Survey and census of howler monkeys (Alouatla palliata) in the rain forest of "Los Tuxtlas," Veracruz, Mexico. Am. J. Primatol. 2: 363-372.

Fedigan, L. M., Fedigan, L., and Chapman, C. (1985). A census of Alouatta palliata and Cebus capusinus monkeys in Santa Rosa National Park, Costa Rica. Brenesia 23: 309-322.

Glander, K. E. (1979). Reproduction and population growth in free-ranging mantled howling monkeys. Am. J. Phys. Anthropol. 53: 25-36.

Glander, K. E. (1982). Feeding patterns in mantled howling monkeys. In Kamil, A., and Sargent, T. D. (eds.), Foraging Behavior: Ecological, Ethological, and Psychological Approaches, New York, Garland Press, pp. 231-259.

Glander, K. E. (1982), the impact of plant secondary compounds on primate feeding behavior. Yrbk. Phys. Anthropol. 25: 1-18.

Glander, K. E. Fedigan, L. M., Fedigan, L., and Chapman, C. (1991). Capture techniques for three species of monkeys in Costa Rica. Folia Primatol. 57: 70-82.

Greenwood, P. J. (1980). Mating systems, philopatry and dispersal in birds and mammals. Anim. Behav. 28: 1140-1162.

Greenwood, P. J. and Harvey, P. H. (1976). The adaptive significance of variation in breeding area fidelity of the blackbird (Turdus merula L). J. Anim. Ecol. 45: 887-898.

Holdridge, L. R. (1967). Life Zone Ecology, tropical Research Center, San Jose, Costa Rica. Hamilton, W. D. (1964). The genetical evolution of social behavior. J. Theoret. Biol. 7: 1-52.

Harcourt, A. H., Stewart, K. S. and Fossy, D. (1976). Male emigration and female transfer in wild mountain gorilla. Nature 263: 226-227

Howard, W. E. (1960). Innate and environmental dispersal of individual vertebrates. Am. Mid. Nat., 63: 152-161. 
Itani, J. (1972). A preliminary essay on the relationship between social organization and incest avoidance in nonhuman primates. In poirier, F. E. (ed.), Primate Socialization, Random House, New York, pp. 165-171.

Jones, C. B. (1980a). The functions of status in the mantled howler monkey (Alouatta palliata) Gray: Instraspecific competition for group membership in a folivorous neotropical primate. Primates 21: 389-405.

Jones, C. B. (1980b). Seasonal parturition, mortality and dispersal in the mantled howler monkey, Alouatta palliata Gray. Brenesia 1: 1-10.

Lidicker, W. Z., Jr. (1962). Emigration as a possible mechanism permitting the regulation of population density below carrying capacity. Am. Nat. 96: 23-29.

Lidicker, W. Z., Jr. (1975). The role of dispersal in the demography of small mammals. In Small Mammals: Productivity and Dynamics of Populations, Petruseqicz, K., Golley, E. B., Ryszkowski, L. (eds.), Cambridge University Press, London, pp. 103-128.

Melnick, D. J., and Pearl, M. C. (1987). Cercopithecines in multimale groups: Genetic diversity and population structure. In Smuts, B. B., Cheney, D. L., Seyfarth, R. M., Wrangham, R. W., and Struhsaker, T. T. (eds.), Primate Societies, University of Chicago Press, Chicago, pp. 121-134.

Milton, K. (1982). Dietary quality and demographic regulation in a howler monkey population. In Rand, A. S., and Windsor, D. M. (eds.), The Ecology of the Tropical Forest, Seasonal Rhythms and Long-Term Change, Smithsonian Institution Press, Washington, D. C., pp. 273-289.

Moore, J., and Ali, R. (1984). Are dispersal and inbreeding avoidance related? Anim. Behav. 32: 94-112.

Neyman, P. F. (1978). Aspects of the ecology and social organization of free-ranging cottontop tamarins (Saguinus oedipus) and the conservation status of the species. Klieman, D. G. (ed.), The Biology and Conservation of the Callitrichidae, Smithsonian Institution Press, Washington, D. C. (in press).

Packer, C. (1979). Inter-troop transfer and inbreeding avoidance in Papio anubis. Animal. Behav. 27: 1-36.

Pope, T. R. (1989). The Influence of Mating System and Dispersal Patterns on the Genetic Structure of Red Howler Monkey Populations, Ph.D. dissertation, University of Florida, Gainesville.

Pope, T. R. (1990). The reproductive consequences of male cooperation in the red howler monkey: Paternity exclusion in multi-male and single-male troops using genetic markers. Behav. Ecol. Sociobiol. 27: 439-446.

Pusey, A. E. (1987). Sex-biased dispersal and inbreeding avoidance in birds and mammals. Tree 2: 295-299.

Pusey, A. E., and Packer, C. (1987). Dispersal and philopatry. In Smuts, B. B. Cheney, D. L., Seyfarth, R. M., Struhsaker, T. T. and Wrangham, R. W., (eds.), University of Chicago Press, Chicago, pp. 250-266.

Rudran, R. (1979). The demography and social mobility of a red howler (Alouatta seniculus) population in Venezuela. In Eisenberg, J. F. (eds.), Vertebrate Ecology in the Northern Neotropics, Smithsonian Institution Press, Washington, D. C., pp. 107-126.

Rumiz, D. I. (1990). Alouatta caraya: Population density and demography in northern Argentina. Am. J. Primatol. 21: 279-294.

Scott, N. J., Jr., Malmgren, L., and Glander, K. E. (1978). Grouping behavior and sex ratio in mantled howling monkeys. In Proceedings of the Sixth International Congress of the International Primatological Society, Academic Press, New York, pp. 183-185.

Sekulic, R. (1982). Behavior and ranging patterns of a solitary female red howler (Alouatta seniculus). Folia Primatol. 38: 217-232.

Sigg, H., Stolba, A., Abegglen, J. J., and Dasser, V. (1982). Life history of hamadryas baboons: Physical development, infant mortality, reproductive parameters, and family relationships, Primates 23: 473-487.

Stewart, K. J., and Harcourt, A. H. (1987). Gorillas: Variation in female relationships. In Smuts, B. B., Cheney, D. L., Seyfarth, R. M., Wrangham, R. W., and Struhsaker, T. T. (eds.), Primates Societies, University of Chicago Press, Chicago, pp. 155-164. 